\title{
Unintended Impacts from Forest Certification: Evidence from Indigenous Aka Households in Congo
}

\author{
Jacqueline Doremus* \\ Cal Poly, San Luis Obispo
}

Sept 26, 2018

\begin{abstract}
Does Forest Stewardship Council certification of "responsible" commercial forestry change nutrition, health and wealth for indigenous peoples, like the Aka of the Congo Basin? Using hand-collected data from the boundary of a certified and an uncertified forest in the Republic of Congo five years after certification, I compare nutrition, health, and wealth using questions that are locally salient and survey timing designed to reach semi-nomadic hunter-gatherers. Though I only observe outcomes after certification, I find suggestive evidence that forest certification may cause increased food insecurity and illness frequency for Aka households. I find no evidence of increased material wealth; instead, the poorest 15 th percentile is poorer. Forest certification includes a bundle of activities, including participatory mapping, greater market integration and hunting restrictions, making it difficult to pinpoint the mechanisms driving these results.
\end{abstract}

JEL: Q56, O13, O18

Keywords: Forestry; eco-label; sustainability; indigenous peoples

*Assistant Professor of Economics in the Orfalea School of Business at California Polytechnic State University - San Luis Obispo, 1 Grand Avenue, San Luis Obispo, CA 93407, jdoremus@calpoly.edu. 


\section{Introduction}

The Congo Basin is home to the second largest tropical forest in the world and an estimated 30-60 million forest-dependent people (Chao 2012), of whom about one million may be indigenous hunter-gatherers (Olivero et al. 2016). ${ }^{1}$ For Aka hunter-gatherers of northern Congo, well-being depends on daily interactions with the forest. ${ }^{2}$ BaAka commonly believe that "Komba (God) created the forest for Yaka people to share" (Lewis 2000: 3). Over the last few decades, BaAka have increasingly shared the forest with commercial timber firms (see Figure 1).

Tensions between commercial timber extraction and local forest users' rights catalyzed the creation of the Forest Stewardship Council (FSC). FSC is a non-governmental organization that defines an international standard for "responsible" forest management. At an early meeting in 1992, stakeholders insisted that changes to the standard's Principles and Criteria "should include a strong role for indigenous peoples and for local forest communities" (Dingwerth 2008: 56). A broad principle to protect forest-dependent and indigenous peoples' use rights resulted (FSC 1996).

Are indigenous peoples living within a commercial forest better off if the forest certifies FSC? Evaluations of FSC's commercial forestry standard have been limited to deforestation

\footnotetext{
${ }^{1}$ Estimates of the number of forest-dependent and indigenous peoples vary greatly because they are not consistently sampled in large-scale, public datasets.

${ }^{2}$ Indigenous peoples are recognized as those who have ancestral claims to natural resources, are culturally distinct from majority ethnic groups, and have been historically marginalized from policy processes governing their use (Colchester 1994). Aka in Northern Congo call themselves "first people" (Lewis 2000) and fit within Colchester's definition of indigenous peoples. They share the forest with Kaka and Bondongo, ethnic groups that spend more time in the village but would satisfy several of the criteria of forest-dependent people (Newton et al. 2016).
} 
(Blackman et al. 2018), forest degradation (Doremus 2015), and forestry practices and prices (Nebel et al. 2005). We lack evidence that FSC ensures indigenous peoples' use rights and their economic well-being.

This gap may be due to three empirical challenges. First, consistent assessment of indigenous peoples' well-being is costly; we lack basic cross-sectional data and panel data are rarer still. Hunter-gatherers move seasonally within the forest and prefer areas far from roads, making censes costly (Olivero et al. 2016). Second, specificity of livelihoods to the local environment, when combined with low population density, makes it difficult to construct an appropriate counter-factual. Finally, measuring hunter-gatherer well-being is fraught. Indigenous peoples may have different ethical systems and definitions of well-being that do not map neatly into utilitarian frameworks (Choy 2018). ${ }^{3}$ Many hunter-gatherers in the Congo Basin live in extreme material poverty, in an exchange economy, with low literacy and numeracy rates (Jackson 2006). Forests contribute toward a large share of indigenous peoples' consumption or earnings (Godoy et al. 2002) and contributions to income from forests may be missed in most survey instruments (Wahlén 2017). Together, these challenges make it difficult to credibly assess how activities to satisfy FSC affect well-being for indigenous peoples.

To address these challenges, I designed and implemented a survey to measure economic well-being of Aka households along the boundary of a certified commercial forest and an uncertified commercial forest in Congo. Congo leads the world in the share of its timber

\footnotetext{
${ }^{3}$ Choy (2018) describes the system of adat used in by the Sarawak in Malaysia, as well as difficulties in reconciling it within a price-based cost-benefit analysis framework. For the Aka of the Congo Basin, anthropologist Jerome Lewis describes an exchange system where goods are given freely when demanded but knowledge is intellectual property that is exchanged for goods or money (Lewis 2015).
} 
that is FSC certified. Exposure to certification is quasi-random; firms choose to certify based on expected profitability, not characteristics of the local population (Doremus 2018). People on the uncertified side serve as a counter-factual for people exposed to certification. A spatial discontinuity ensures that hyper-local features are similar for treated and control groups.

I focus on three outcomes that proxy for economic well-being - composition of the household's previous meal, whether or not an individual was recently ill, and an inventory of material assets. The survey emphasized locally salient outcomes with timeframes designed to elicit good data in a context without access to written records (Lenzner et al. 2010). Survey timing was explicitly designed to reach Aka hunter-gatherers when they were most likely to spend time in the village.

My null hypothesis is that certification fails to change outcomes for indigenous households. I find evidence that certified Aka households' nutrition, health, and wealth differ in a surprising way: they are worse. Certified Aka households are more likely to go hungry over the previous two days. Certified Aka individuals are more frequently ill over the previous two weeks. Certified households have greater material wealth inequality: the poorest $15 \%$ are poorer than the poorest $15 \%$ of uncertified households.

This paper contributes to a better understanding of FSC's efficacy in achieving its stated aims. Despite the certified firm's innovation and commitment to ensuring indigenous peoples' forest access, exposure to the set of FSC activities likely made Aka households worse off. Though surprising, these results concord with work by anthropologists. Jost Robin- 
son and Remis (2016) found that among Aka women exposed to market integration and hunting restrictions, older women had lower body fat and increased inflammatory markers. Riddell (2013) found that within villages exposed to commercial forestry and conservation activities, Aka likelihoods changed more as compared to villages with less exposure. Lewis (2016) points to violence against BaAka by "eco-guards," which restricts access to the forest. Together, these studies point to a potential failure of FSC to address tensions between commercial forestry, conservation and indigenous peoples' rights - the very concerns that launched FSC twenty years ago.

\section{Study Setting}

The study takes place along the Upper Motaba River in the Republic of Congo. Figure 1 locates the study site within the Congo Basin forest, second in size only to the Amazon forest and heavily allocated to commercial logging. I begin by describing firm activity along the Motaba River and then briefly characterize the village economy along the Motaba River.

\subsection{Timber Firm Activities Along the Motaba River}

Situated in northern Republic of Congo, the Motaba River acts as a boundary between a certified and uncertified forest management unit (FMU). Both FMUs are large, over half a million hectares. They each include about a dozen small villages and forest camps and their estimated populations are around five thousand people each. Firms cannot certify only part of their forest concession. The households surveyed make up $6 \%$ of the inhabitants of the 
Loundoungou-Toukoulaka forest management unit. Though household characteristics may affect the cost of complying with FSC's rural development mandate, the magnitude of these costs is likely dwarfed by costs from changes in timber production and new revenues from an FSC price premium. Loundoungou-Toukoulaka is the last of three contiguous forest management units managed to be certified, making the total certified area over 1 million hectares. ${ }^{4}$

De jure, all forest management units have obligations to the communities that live in their forests. These obligations, known as the cahiers des charges, are the product of negotiations between the firm and the Congolese State. A frequent critique is that they are incompletely implemented (Karsenty and Pierre 2005). For the uncertified FMU along our boundary, the only cahiers des charges activities reported by village leaders were the distribution of some agricultural tools. By selecting the Motaba River boundary, we construct a counter-factual of local outcomes under typical uncertified timber management, which implies few services for local households.

\subsection{Compliance with FSC Standard}

Forest Stewardship Council's (FSC) Forest Management Certification is the best-known forestry management standard and is highly regarded among all types of eco-labels. Ten principles and criteria are used to assess compliance. Among these, three are most relevant to this study: those concerning rural development, indigenous peoples' rights, and controlled hunting. Principle three states that "Indigenous peoples' rights The legal and

\footnotetext{
${ }^{4}$ See Doremus (2018) for more on drivers of participation in forest certification.
} 
customary rights of indigenous peoples to own, use and manage their lands, territories, and resources shall be recognized and respected." Principle four states that "forest management operations shall maintain or enhance the long-term social and economic well-being of ... local communities" (FSC 1996).

CIB implemented two innovative programs to respond to principles three and four of the FSC standard. The first was a participatory mapping program developed with help from The Forest Trust, the World Bank, anthropologist Jerome Lewis, and Helveta, a technology company. The result was a unique GPS mapping process co-developed by Aka men and women that used icons and did not require literacy (Clark and Poulsen 2012: 67). BaAka used the GPS units to create community maps that identified key resources, like trees preferred by caterpillars or sacred places. These resources were then built into CIB's harvesting plans and marked in the forest to ensure protection. Second, CIB hosted a local language radio program called Biso na Biso, which featured programs in twelve local languages on 88.0 FM. BaAka songs and and interviews were featured on the radio, as well as information related to CIB's timber harvesting and FSC practices (Clark and Poulsen 2012: 68).

The timeline for the study site, Figure 2, begins in 2002. The certified firm, Congolaise Industrielle du Bois (CIB), received rights to timber production in Loundoungou FMU for a period of fifteen years in 2002. Production began in 2003, the same year that production began in the uncertified Ipendja FMU by Thanry Congo. ${ }^{5}$ In 2007, CIB resurfaced the road

\footnotetext{
${ }^{5}$ In 2005, Loundoungou and Toukoulaka FMU were combined into one FMU. The FMU in Figure 2 includes both FMUs.
} 
connecting the Loundoungou sawmill town to the village of Makao and built a bridge across the Motaba River. This is the road sweeping from the bottom left corner of Figure 2 to the towns of Makao and Ipendja. ${ }^{6}$ Among CIB's activities to satisfy FSC's rural development mandate was the construction of a feeder road that connected five villages to the broader road network in 2007. Road-resurfacing is a common way firms fulfill these obligations in the Congo Basin. ${ }^{7}$

Though the risks of roads to indigenous peoples' health and well-being in the Congo Basin is infrequently recognized, the risks to local defaunation are well-understood (Wilkie et al. 2000). Roads facilitate access to fauna by hunters and trade of bushmeat. Recognizing this, the Congolese state requires all forests to implement controlled hunting protocols, however this requirement is poorly enforced. FSC's criterion 6.2 states that "inappropriate hunting, fishing, trapping and collecting shall be controlled" (FSC 1996). The FSC-certified firm is recognized as having one of the most sophisticated and far-reaching anti-poaching programs in the region (Clark and Poulsen 2012). Activities to satisfy criterion 6.2 include control posts on roads manned by armed "eco-guards" to check for illegal trade in wildlife, required seasonal and annual huntin gpermits, and patrols of hunting zones. Critics have pointed out that these policies hurt hunter-gatherers because they restrict access to the forest and are unfairly enforced (Lewis 2016).

\footnotetext{
${ }^{6}$ The Loundoungou sawmill was constructed between 2008-2009.

${ }^{7}$ Timber firms in the Congo Basin choose to satisfy FSC by resurfacing roads for many reasons. First, road quality is particularly poor in the Congo Basin. Development agencies, such as the World Bank, the IMF, the US Agency for International Development, and the United Nations Development Program all have large programs financing road resurfacing in the Congo Basin. Second, roads are easily monitored by FSC auditors. Third, because timber production in the Congo Basin is selective, these firms are skilled at road-building and can resurface at low cost, in terms of capital, management costs, and materials.
} 


\subsection{The Rural Economy of the Motaba River}

The Motaba River forms the boundary between the certified and uncertified forest concessions. Even with FSC certification and the new road connection, households remain focused on autoconsumption and production of agricultural goods. Logging activities are concentrated in the town that accompanies the sawmill and in the timber camp, which moves about the forest concession. The sawmill site for Thanry is Ipendja, visible in Figure 2, and for CIB it is Loundougou, which is south of this map. Both are several hours drive from the villages along the Motaba. Some households do seasonal work for the timber company, such as helping with forest inventories but firms typically prefer to hire individuals with better literacy and greater experience in timber production.

For this paper, we classify households into two subgroups. BaAka are semi-nomadic indigenous hunter-gatherers that are genetically distinct from more recent arrivals during the Bantu expansion tens of thousands of years ago (Quintana-Murci et al. 2008). ${ }^{8}$ All households along the Motaba can be considered forest-dependent but I use the term "indigenous" to refer to BaAka households and "Bantu" to refer to non-indigenous households. Among Bantu households, two clans live within the study site, Kaka and Bondongo. Both spend more time in the village and spend more time on agricultural practices than BaAka, who spend more time in hunting and fishing camps in the forest.

Over time, BaAka and Bantu farmers developed exchange relationships related to farming. BaAka spend time in their village during the dry season, trading their labor for calorie-rich farmed starch, clothes, medicine, salt, and other non-forest goods from a Bantu

\footnotetext{
${ }^{8}$ The plural of Aka is BaAka or Yaka.
} 
household known as their nkumu (Moukassa et al. 2005, Riddell 2013, Lewis 2000). Historically, access to farmed starch during the dry season has been critical for BaAka for three reasons. One, they need to replenish glycogen stores after spending a long period of time in the forest. Two, foraged starch is less abundant during this time of year, thus farmed starch forms part of an annual starch strategy (Kitanishi 1995). And three, labor for farmer households is physically taxing, requiring a more calorie dense starch.

Before FSC certification, for villages on either side of the Motaba River the primary method of trade was either to travel to a town with a market or to trade with merchants traveling up or down the Motaba by boat (Kitanishi 1995). As seen in Figure 2, directly north and south of the study site are two towns, Makao and Djubé. These towns are much larger, with over one thousand inhabitants each. They have weekly markets active since before the road connection. Merchants travel down the Motaba River by boat selling manufactured goods and buying agricultural goods. People also paddle to markets to sell their goods. The new road connection on the west bank of the Motaba brought merchants and logging employees directly to the village by truck or motorcycle. There is excess demand for food because many of the logging company employees living in Thanry and Loundoungou are from Cameroon, Central African Republic, or the Democratic Republic of the Congo and have trouble negotiating access to land they can cultivate. 


\section{Methodology}

This section begins by describing the process by which I selected the site and collected the data. I then present the empirical framework and assess different threats to identification.

\subsection{Site Selection}

To investigate how forest certification impacts forest-dependent and indigenous households, I began by identifying all boundaries between a certified and uncertified forest in Congo. I then refined this set to include boundaries with a sufficient number of villages nearby on either side of the boundary and located within one administrative unit (département). This resulted in a single possible site, the upper Motaba River. Using a census from a 2010 management plan and anthropologists' records of the seasonality of production and consumption activities (Kitanishi 1995), I conducted a power analysis to ensure sufficient power to identify changes from certification and planned survey timing. The study site includes nine study villages between Makao and Djoubé, two larger towns. Six of the villages were on the west bank and thus exposed to certification activities. Table A1 reports village names, location, and date of visit for each village.

\subsection{Data Collection}

I used a simple census of all households along the Upper Motaba River as my sampling scheme. Survey data collection began November 2012 and ended February 2013, spanning 79 days during the main dry season. I chose this time period because it made it most likely 
we would meet with Aka households in the village (Kitanishi 1995;Riddell and Obongo 2011) and to ensure that all surveys occurred during the same agricultural season. I randomized the order of the timing of visits to each village prior to the start of the survey.

I translated and adapted a survey instrument to better reflect local characteristics and piloted the survey in the town of Makao. The Troisième Enquête Camerounaise auprès des Ménages (ECAM3) survey instrument used in Cameroon in 2007 served as the base. I added questions used by an anthropologist assessing changes in hunting behavior (Riddell 2013). I then translated the survey into English and Lingala. I piloted question wording and defined local units of measurement in Makao. The survey was given in either French or Lingala, with BaAka translating on the fly if needed. Each household survey took no more than 2 hours. I used a tablet, coding the survey in XML and used Kobo Collect software, which accommodated built-in skip logic. Questions and remuneration for participation were approved by the University of Michigan Internal Review Board. Funding for data collection came from the Department of State's Fulbright Program and several small grants managed by the University of Michigan.

Each round of surveys began with an initial census of all dwellings in the village. Comparing surveys to census dwelling data, 51 households were absent during our stay in the village and 197 households started the survey. Participation was voluntary and either the enumerator or the household could refuse participation. Nine households refused to participate when initially approached. The primary reason given for refusal was that the occupants were too old or unwell to participate. Participants or the enumerator could 
choose to stop the survey at any time. Eight households started but did not finish the survey. These households provided data on their meals and health but not their material wealth data, which was collected at the end of the survey. ${ }^{9}$

\subsubsection{Outcome Variables}

From the survey I focus on variables that measure three outcomes: nutrition, health, and wealth. For nutrition, I asked respondents about the household's meals over the previous two days. I then classified whether meals had any protein or any farmed starch. A household was recorded as having not consumed farmed starch if they did not list manioc, sweet potato, taro, yam, plantain or rice. A household was recorded as having not consumed protein if they failed to list meat or fish. In Table 1, we see that $14.2 \%$ of households failed to report eating starch the previous day, $15.2 \%$ the day before that, and $7.6 \%$ failed to report eating starch either day. Protein is missed more frequently; 33\% of household failed to report eating protein the previous, $25.9 \%$ the day before that, and $13.7 \%$ report no protein either day. ${ }^{10}$

For health, I asked respondents whether they had been ill over the last two weeks. This question was posed to all individuals within the household, for a total of 896 observations, of which $77 \%$ reported being ill recently. For material wealth, I used an inventory of

\footnotetext{
${ }^{9}$ Surveys were intended to include all inhabitants of the Bobate neighborhood of Bangui-Motaba (certified). However, after surveys began, leaders within the neighborhood insisted on additional neighborhood fees and gifts for continued participation. Surveys ceased, resulting in completed surveys for 11 households and 31 households that were present but not surveyed. Because the conflict that provoked termination of survey activity occurred among leaders and not households, I do not expect systematic bias across households missing and included from Bobate. Regressions include the 11 Bobate households but results are robust to restricting the sample to neighborhoods with full participation.

${ }^{10}$ About $8 \%$ of households report eating neither starch nor protein the previous day or the day before.
} 
belongings adapted from Riddell (2013) and prices assessed across two vendors in Makao in 2012. ${ }^{11}$ The average value of assets was about 84,000 FCFA or 168 US dollars.

\subsection{Empirical Framework}

This study's empirical strategy exploits a discontinuous change in forest management regime across the Motaba River. I compare households on the certified bank of the river to households on the uncertified bank with a focus on differential impacts for indigenous households. The Motaba River boundary forms a discontinuity in longitude-latitude space. The main regression specification is

$$
\text { outcome }_{h v}=\alpha+\beta_{1} \text { Cert }_{v}+\beta_{2}\left[\text { Cert }_{v} * \text { Bantu }_{h}\right]+\beta_{3} \text { Bantu }_{h}+\gamma \text { Female }_{h}+\epsilon_{h v}
$$

where $C_{e r t}$ is the an indicator equal to one if the village is on the certified east bank of the Motaba River and equal to zero otherwise. The coefficient $\beta_{1}$ describes the average marginal effect of certification for indigenous households, the omitted group. Bant $u_{h}$ is a dummy variable equal to one if the household is not indigenous. The interaction term captures the differential effect of certification on Bantu households. Female is a dummy variable equal to one if the household head is female. For the illness regressions, we use data at the individual level and include a linear and quadratic $a g e_{i}$ term. When investigate material wealth, I use quantile regressions at the $15 \mathrm{th}, 50 \mathrm{th}$, and 85 th percentiles in addition to an

\footnotetext{
${ }^{11}$ Since eight households did not complete the survey, material wealth has 189 observations instead of 197.
} 
OLS regression. ${ }^{12}$ I also break out BaAka and Bantu subgroups for the quantile regressions because of their very different wealth distributions.

The identification strategy echoes Dell et al. (2017), who compare historical and contemporary outcomes across a colonial administrative boundary in Vietnam. My regression specification is much simpler than Dell et al. (2017) because my data, study area and variation along the boundary is more limited. ${ }^{13}$ First, due to budget constraints I only observe villages directly along the study boundary; this eliminates the need for a border bandwidth. Second, the pattern of settlement along the Motaba River limits the latitudinal and longitudinal variation within the treatment and control groups. The implication for the regression specification is that we cannot separately identify differences in latitude and longitude from differences from certification. I address this threat to identification in more detail below.

Selection criteria for the study was at the village level because villages are assigned to treatment based on their location in latitude and longitude space. Treatment is clustered within a village and thus we cluster standard errors at the village level (Abadie et al. 2017). This choice is similar to Dell et al. (2017), who cluster by sub-administrative unit. Unlike Dell et al. 2017, we have few clusters. There are nine villages; with this few clusters, we are likely to over-reject the null (Bertrand et al. 2004). The best way to address this problem is to use a wild cluster bootstrap (Cameron et al. 2008). However, for very few clusters, like

\footnotetext{
${ }^{12}$ These quantiles were selected to give a sense of the distribution; we are limited to a coarser set of quantiles because the set of observations is small.

${ }^{13}$ Like Dell et al. (2017), I also experimented with including a distance to the nearest town. This variable failed as a significant predictor for all study outcomes, likely because there are towns on either end of the study area so there is little variation within treatment and control groups.
} 
in my case, the wild cluster bootstrap may over- or under-reject. MacKinnon and Webb (2018) show that the subcluster wild bootstrap performs better when there are fewer than 13 clusters. We use the subcluster wild bootstrap, clustering regression standard errors at the village level but bootstrapping at the individual or household level using the boottest command (Roodman et al. 2018). We use a six-point distribution because this performs better than traditional Rademacher weights when there are less than eleven clusters (Webb 2013).

\subsection{Identifying Assumption and Threats to Identification}

The study design eliminates the risk that unobserved household characteristics drive selection into treatment. A firm's decision to participate in FSC depends on the expected profitability of participation, which does not depend on local population (Doremus 2018). This makes a household's exposure to certification activities as good as randomly assigned at the village-level.

Our identifying assumption is that there is no discontinuous change in unobserved household characteristics across the Motaba River or at 17.32 degrees longitude. ${ }^{14}$ If unobserved household characteristics change sharply at these boundaries, estimated differences across certified and uncertified households would reflect ex ante differences instead of changes from certification. To test this assumption, I include balance tests of several persistent household characteristics in Table 2. The left column reports the average for certified villages, the

\footnotetext{
${ }^{14}$ The historical settlement pattern along this short stretch of the Motaba River is such that villages north of 17.32 degrees longitude are on the west (certified) bank and villages south of this are located on the east (uncertified) bank.
} 
right the average for uncertified villages, and the final column is the p-value for a two-sided t-test. I fail to find differences across likelihood to fish, farm, attend school, be able to read, the household size, and other characteristics. The only characteristic that differs is the likelihood the household head is female. Female-headed households are poorer and less likely to report consuming protein. A higher frequency of female-headed households in uncertified villages means we may be more likely to overestimate meal and wealth benefits from certification. To control for persistent differences across male- and female-headed households, I include a dummy variable, Female ${ }_{i}$, in all regression specifications.

\subsubsection{Main Threat: Sorting in Response to Treatment}

The main identification threat is if households sort in response to certification activities. With sorting, the estimated coefficient $\beta_{C}$ would reflect changes in the distribution of households instead of the difference between treated and control households. The balance tests in Table 2 provide some assurance that we do not find strong evidence of sorting. However, a higher frequency of female-headed households in uncertified villages could be an indication of higher emigration out of uncertified villages.

One certification activity in particular, a road connection, could change village composition by changing emigration incentives. Roads may increase or decrease emigration, depending on how changes in local wages and prices compare to changes in migration costs (Morten and Oliveira 2016). Empirically, several authors find that roads reduce emigration. $^{15}$

\footnotetext{
${ }^{15}$ In Nepal, road presence was associated with less emigration (Fafchamps and Shilpi 2013) and in Tanzania, roads reduced migration on average (Gachassin 2013). In India, roads do not lead to changes
} 
I use three different approaches to assess whether patterns of emigration differ across certified and uncertified villages. First, I compare populations during my census, in 2012, with a 2007 census done by the uncertified logging company (Bikoumou and Mboussi 2010). For each census, the unit of observation was ethnicity-village population. A two-sided ttest comparing the change in population since 2007 failed to reject the null hypothesis that population change was the same in certified and uncertified villages ( $\mathrm{p}$-value $=0.43$ ).

Second, I plot a histogram of household formation across time for certified and uncertified households in Figure AI. If we see a sharp uptick in arrivals in certified villages starting about five years before, this would be evidence of increased immigration into certified villages. Differences in the pattern of arrivals over time could also indicate difference in emigration. From the figure, we see that the patterns of household arrival look very similar across exposure to certification activities.

Third, to evaluate emigration out of the study area I can compare the fraction of households absent when the survey was conducted. The likelihood a household is absent is similar across certified and uncertified villages, $16 \%$ and 20\%, respectively. Fourth, we may expect migrants to be more educated than those that remain and men may migrate more frequently (Chiquiar and Hanson 2005; Fafchamps and Shilpi 2013). Table 2 reports t-tests from survey questions related to education and sex. Though certified villages have higher rates of literacy and school attendance, we fail to reject the null that the rates are the same for certified and uncertified villages.

in village populations (Asher and Novosad 2016). Authors in Bangladesh cite zero attrition in panel households before and after road rehabilitation, though this may not capture emigration by individuals within the household (Khandker and Koolwal 2010). 
Together, there is weak evidence that certification activities reduced emigration out of certified villages. However, if road connection reduced emigration by educated, productive men in treated villages, we would expect our estimates of protein meal frequency and the value of material assets to be biased upward.

\section{Results}

In this section I focus on differences in nutrition, health and wealth across exposure to FSC activities. The first section focuses on nutrition, specifically the composition of a household's meals over the last two days. The next section focuses on the frequency of illness, measured at the level of an individual. The final section focuses on the value of a household's assets, assessed during a household inventory.

\subsection{Composition of Recent Meal}

Table 3 reports results for the composition of a household's recent meal. The two panels report the likelihood of reporting no starch consumption (top panel) or no protein consumption (bottom panel). The three columns are different horizons. The first column is for the previous day's meal, the second is for the meal two days ago, and the final column is for the two day period (previous day and day before). The outcome variable is equal to one if the household failed to report eating starch or protein the previous day, the day before that, or ever over the course of the last two days. Standard errors clustered by village are reported in parentheses. P-values from subcluster wild bootstrapped standard errors are 
reported in brackets below each coefficient estimate.

Focusing on the first line of the top panel, we find certification consistently increases the likelihood a household reports not consuming starch. The coefficient Certified describes the change in the likelihood an Aka household reports not consuming starch when exposed to forest certification activities. Across the three regressions, the coefficient is positive. For the previous day, certified households are more likely to report failing to consume farmed starch with a p-value of 0.099. For the meal two days ago, certified households are 30 percentage points more likely to report failing to consume farmed starch; the estimate is significant at the $1 \%$ level. This is an increase of over 200 percent as compared to uncertified households (the unconditional likelihood of no farmed starch two days ago is 15\%).

The pattern holds for consumption over the last two days. Certified households are 12.5 percentage points more likely to report consuming no starch over the last two days and this estimate is significant at the $5 \%$ level. Most households consume starch every day; the unconditional likelihood of a gap in farmed starch consumption over the last 48 hours is about $8 \%$. Certification increases the likelihood of a gap by nearly $150 \%$.

Moving down the table, we see that certification has a differential effect on Bantu households' starch consumption. The interaction term is negative, statistically significant, and nearly perfectly offsets the average effect. For each regression, we fail to reject the null that certification has no effect on starch consumption for Bantu households. In general, Aka households are more likely to report missing farmed starch, independent of certification. Despite their already lower consumption frequency, exposure to certification activities 
appears to have a differential, negative effect on BaAka starch consumption.

In the second panel, we find a similar pattern for protein consumption by Aka households. Households exposed to forest certification activities are more likely to report not consuming protein in recent meals. Here the effect size is larger for the most recent horizon: Certified households are 32 percentage points more likely to report no protein in their last meal and the estimate is statistically significant at the $5 \%$ level. Certified households are 19 percentage points more likely to report no protein in a meal in the recent past; this estimate is statistically significant at the $10 \%$ level. Finally, certified households are 15 percentage points more likely to report no protein consumption over the last two days and the estimate is significant at the $1 \%$ level.

Unlike in the top panel, we find evidence of a shared change in protein consumption for certified Bantu households. For the most recent meal, we fail to reject the null that certification has no impact on the frequency of protein consumption by Bantu households: the p-value for the linear combination of the average and differential effect for Bantu households is 0.19 for column 1. Similarly, the p-value for the linear combination is 0.14 for the gap in protein over the last two days (column 3). However, for the previous day, we reject the null that there is no change in consumption for Bantu households at the $5 \%$ level. Unlike starch, female-headed households have a lower likelihood of consuming protein.

Considered jointly, the estimates from this table bring us pause. We find that certified Aka households consume less starch and all certified households consume less protein. Most troublingly, we see an increase in the frequency households report not consuming any starch 
or any protein over the last two days. The survey was implemented during a time when work was particularly labor intensive; calorie and amino acids needs are particularly high for BaAka at this time of year (Kitanishi 1995). The calorie and amino acid shortfalls implied by the lack of starch and protein access suggest households are not getting enough food to eat. To test for food insecurity, the next section investigates the frequency of illness among household members.

\subsection{Frequency of Recent Illness}

Table 4 reports coefficient estimates for the frequency of an individual's recent illness. Recent, in this case, encompasses the previous two weeks. The first column includes all survey respondents who finished the questionnaire. The next three columns break out the sample by age: adults older than 45, people between 10 and 45, and children under ten. There are three panels; the top includes all individuals, the middle women and girls, the bottom men and boys.

Focusing on the first row, we see that on average exposure to certification activities increases the frequency of illness. Individuals exposed to certification are 13 percentage points more likely to report recently being ill and the estimate's p-value is 0.001 . Moving to the second column, we see that this effect is driven by older adults: older adults exposed to certification are 28 percentage points more likely to be ill recently. In columns 2 and 3 , though the coefficients are positive, the estimates are not statistically significant. Like in the case of starch consumption, the interaction term for the effect of certification on Bantu 
individuals is negative and offsets the average effect.

Panels B and C group the population by sex. The average effect is similar for men and women and has the same magnitude as the population estimate: 13 percentage points. However these similarities mask different responses across older and younger people. Among females, it is older Aka women who report the greatest increase of illness: a 47 percentage point increase that is statistically significant. Women of childbearing age and girls fail to show an increase in reported illness. If activities to satisfy FSC certification reduce forest access and increase market integration, this result woult concord with results from anthropologists in nearby Central African Republic (Jost Robinson and Remis 2016). Among males, Aka boys exposed to certification activities are 17 percentage points more likely to report being sick recently. Boys illness could decrease if they have less opportunity to practice and grow skilled at hunting through defaunation or reduced access to the forest.

\subsection{Material Assets}

Table 5 reports the difference in the value of material assets for households exposed to certification activities. The outcome variable is the natural log of the value of a household's assets, measured in FCFA. ${ }^{16}$ Figure III plots histograms of material asset value for BaAka and Bantu households. The distributions differ - BaAka households tend to be much poorer - creating a bimodal distribution when grouped. For this reason, I broke the sample into two for the main regressions. In Table 5, the top panel is BaAka households and the bottom panel is Bantu households. The first column reports coefficient estimates from an ordinary

\footnotetext{
${ }^{16}$ In 2012, along the Motaba, 500 FCFA was about 1 USD.
} 
least squares regression. Columns two through four present coefficients from bootstrapped quantile regressions for the 15 th, 50 th, and 85 th percentiles.

Focusing first on the top panel, the coefficient for the certification dummy in the OLS estimate, in column one, is -0.10 and statistically insignificant. This estimate is not far from the coefficient for the quantile regression of the 50th percentile, which is -0.089 and also statistically insignificant. Comparing across the quantile regressions in columns 2 through 4, we see that the distribution of certified households has greater inequality: the coefficient for certification is negative for the bottom of the distribution and positive for the top of the distribution. The increase in inequality is driven by decreases at the bottom of the distribution: the poorest 15th percent of certified indigenous households are 34 percentage points poorer than the poorest 15th percent of uncertified indigenous households and the estimate is statistically significant at the $5 \%$ level. Turning to the second panel of Table 5 , the pattern of results and coefficient magnitudes are similar for Bantu households, however the quantile for the 15 th percentile is no longer statistically significant.

Figure IV plots the estimated coefficient for certification at different deciles from a quantile regression using the grouped population, BaAka and Bantu households. The dashed line is the OLS estimate of the certification coefficient, which is -0.069 . Near the median, the two estimates are similar. The coefficient is increasing in quartiles, which implies that certified households have greater income inequality. The confidence interval for lower quartiles is below zero;we reject the null that there is no difference in material assets for certified and uncertified households in bottom quartiles. 


\section{Conclusion}

This paper uses a spatial discontinuity in exposure to activities to satsify Forest Stewardship Council's forest management standard in northern Republic of Congo to assess how FSC certification changes nutrition, health, and wealth for indigenous and forest-dependent households. A specially designed survey was timed to target indigenous Aka households and measure salient outcomes in a low literacy, extreme material poverty context.

I found that Aka households exposed to certification had worse nutrition outcomes: they more frequently failed to report eating farmed starch or protein. Aka individuals exposed to certification also reported more frequent recent illness, particularly older women and young boys. I found that the poorest 15 th percentile of households exposed to certification were 43 percentage points poorer than the poorest 15th percentile of households not exposed to certification. The distribution of material wealth among certified households was more unequal than among uncertified households.

A negative impact on wealth stands in contrast to recent work investigating the effectiveness of FSC-certified community forestry. FSC-certified community forestry is associated with increased incomes in Guatemala (Bocci et al. 2018) and Tanzania (Kalonga and Kulindwa 2017). In community forestry, the local community has the right to fell and sell certified timber, in contrast with commercial forestry, where a firm extracts timber and is mandated to respect local use rights and offer compensation for extraction.

Two features of the study limit the generalizability of these results. Like other settings that exploit a spatial discontinuity (Dell 2010, Dell et al. 2017), I only observe outcomes 
after treatment. I cannot directly verify that households did not sort in response to treatment. However, I test persistent household characteristics and find them to be comparable. Second, the population of households interviewed is small and I only investigate one boundary. These are the tradeoffs of keeping the local environment very similar across the treated and control groups and ensuring good BaAka representation.

Reduced food security and wealth run counter to the goals that catalyzed the creation of FSC and made it such a promising policy innovation in the nineties. It is unlikely that these results come from an explicit agenda by the certified timber company to harm indigenous peoples. It is more likely that these results are an unintended consequence of other FSC activities, including road building, increased market integration, and restricted hunting and forest use. Anthropologists Remis and Jost Robinson (2014) and Riddell (2013) found similar patterns when comparing BaAka across villages more and less exposed to market integration and hunting restrictions.

More broadly, these results add to an emerging body of evidence that shows that despite tough criteria and credible monitoring, FSC certification of commercial timber firms may fail to change behavior in desired ways. Blackman et al. (2018) find no evidence that participation in FSC changes deforestation rates. Doremus (2015) finds no change in forest degradation due to firms gaming the auditor's baseline. Instead of changing behavior, FSC may be more useful in credibly revealing the firms that find it less costly to practice less destructive harvesting. Doremus (2018) finds that forests with the lowest opportunity cost participate in FSC and Foster and Gutierrez (2013) find that FSC is useful for targeting 
local monitoring resources.

More empirical work is critical as we reconsider the wisdom of eco-labels like FSC as a policy tool (Bonroy and Constantatos 2015). FSC as a signal for less destructive harvesting is insufficient for ensuring use rights and well-being for indigenous peoples. When asked to compare the past to today, Maindja, a 45 year old Aka grandmother, said "Our life has turned upside down! And nobody cares. If we walk in the forest we are taken by eco-guards... Listen! We don't eat meat anymore! This is what the state has done to us" (Lewis 2016: 376). We urgently need better communication with indigenous peoples to improve assessment of existing policies, like FSC, as well as to help us, together, creatively re-imagine new, different policy tools to ensure well-being for those exposed to commercial logging. 


\section{References}

Abadie, Alberto, Susan Athey, Guido W Imbens, and Jeffrey Wooldridge, "When should you adjust standard errors for clustering?," NBER Working Paper, November 2017, 24003.

Asher, Sam and Paul Novosad, "Market access and structural transformation: Evidence from rural roads in India," 2016. Working paper.

Azevedo, Joao Pedro, "GRQREG: Stata module to graph the coefficients of a quantile regression," Statistical Software Components, Boston College Department of Economics January 2004.

Bertrand, Marianne, Esther Duflo, and Sendhil Mullainathan, "How much should we trust differences-in-differences estimates?," The Quarterly Journal of Economics, 2004, 119 (1), 249-275.

Bikoumou, Séraphin and Alain Serge Ndolo Mboussi, "Rapport de l'étude socioeconomique: plan d'aménagement de l'UFA IPENDJA," Technical Report, Sociéte Thanry Congo January 2010.

Blackman, Allen, Leonard Goff, and Marisol Rivera Planter, "Does ecocertification stem tropical deforestation? Forest Stewardship Council certification in Mexico," Journal of Environmental Economics and Management, 2018, 89, 306-333.

Bocci, Corinne, Lea Fortmann, Brent Sohngen, and Bayron Milian, "The impact of community forest concessions on income: an analysis of communities in the Maya Biosphere Reserve," World Development, 2018, 10\%, 10-21.

Bonroy, Olivier and Christos Constantatos, "On the Economics of Labels: How Their Introduction Affects the Functioning of Markets and the Welfare of All Participants," American Journal of Agricultural Economics, 2015, 97 (1), 239-259.

Cameron, A Colin, Jonah B Gelbach, and Douglas L Miller, "Bootstrap-based improvements for inference with clustered errors," The Review of Economics and Statistics, 2008, 90 (3), 414-427.

Chao, Sophie, Forest Peoples: Numbers across the world, Forest Peoples Programme, 2012 .

Chiquiar, Daniel and Gordon H Hanson, "International migration, self-selection, and the distribution of wages: Evidence from Mexico and the United States," Journal of Political Economy, 2005, 113 (2), 239-281.

Choy, Yee Keong, "Cost-benefit Analysis, Values, Wellbeing and Ethics: An Indigenous Worldview Analysis," Ecological Economics, 2018, 145, 1 - 9. 
Clark, Connie J and John R Poulsen, Tropical forest conservation and industry partnership: an experience from the Congo Basin, Vol. 14, John Wiley \& Sons, 2012.

Colchester, Marcus, Salvaging nature: indigenous peoples, protected areas and biodiversity conservation, Vol. 55, Diane Publishing, 1994.

Dell, Melissa, "The persistent effects of Peru's mining mita," Econometrica, 2010, 78 (6), 1863-1903.

_ , Nathaniel Lane, and Pablo Querubin, "The historical state, local collective action, and economic development in Vietnam," Technical Report, National Bureau of Economic Research 2017.

Dingwerth, Klaus, "Global Governance," Global Governance, 2008, 14, 53.

Doremus, Jacqueline M., "Three Essays on the Effectiveness of Voluntary Forest Certification." PhD dissertation, University of Michigan 2015.

_ , "How Does Eco-Label Competition affect Environmental Benefits? The Case of Central Africa's Forests," Working Paper, 2018.

Fafchamps, Marcel and Forhad Shilpi, "Determinants of the choice of migration destination," Oxford Bulletin of Economics and Statistics, 2013, 75 (3), 388-409.

Foster, Andrew D and Emilio Gutierrez, "The informational role of voluntary certification: evidence from the Mexican clean industry program," American Economic Review, 2013, 103 (3), 303-08.

FSC, "FSC International Standard: Principles and Criteria for Forest Stewardship," 1996.

Gachassin, Marie Castaing, "Should I Stay or Should I Go? The Role of Roads in Migration Decisions," Journal of African Economies, 2013, 22 (5), 796-826.

Godoy, Ricardo, Han Overman, Josefien Demmer, Lilian Apaza, Elizabeth Byron, Tomas Huanca, William Leonard, Eddy Perez, V Reyes-Garcia, Vincent Vadez et al., "Local financial benefits of rain forests: comparative evidence from Amerindian societies in Bolivia and Honduras," Ecological Economics, 2002, 40 (3), 397409.

Jackson, Dorothy, "The health situation of women and children in central African Pygmy peoples," Indigenous affairs, 2006, (1), 38-45.

Kalonga, Severin Kusonyola and Kassim Athumani Kulindwa, "Does forest certification enhance livelihood conditions? Empirical evidence from forest management in Kilwa District, Tanzania," Forest Policy and Economics, 2017, 74, 49-61. 
Karsenty, Alain and Jean-Michel Pierre, "Les concessions forestières en Afrique Centrale. Aspects historiques, institutionnels et politiques, du point de vue de la responsabilité sociale et environnementale des entreprises concessionnaires: Etude pour le projet GEPAC (Contribution à l'amélioration des processus de gouvernance environnementale et de gestion participative en Afrique centrale) de l'Union Européenne," 2005.

Khandker, Shahidur R. and Gayatri B. Koolwal, "How Infrastructure and Financial Institutions Affect Rural Income and Poverty: Evidence from Bangladesh," Journal of Development Studies, 2010, 46 (6), 1109-1137.

Kitanishi, Koichi, "Seasonal Changes in the Subsistence Activities and Food Intake of the Aka Hunter-Gatherers in Northeastern Congo," African Study Monographs, 1995, 16 (2), 46 .

Lenzner, Timo, Lars Kaczmirek, and Alwine Lenzner, "Cognitive burden of survey questions and response times: A psycholinguistic experiment," Applied Cognitive Psychology, 2010, 24 (7), 1003-1020.

Lewis, Jerome, "Forest People or Village People: Whose voice will be heard?," in "Annual International African Studies Conference" May 2000.

_ , "Where goods are free but knowledge costs: Hunter-gatherer ritual economics in Western Central Africa," Hunter Gatherer Research, 2015, 1 (1), 1-27.

_ , "Our life has turned upside down! And nobody cares.," Hunter Gatherer Research, 2016, 2 (3), 375-384.

MacKinnon, James G and Matthew D Webb, "The wild bootstrap for few (treated) clusters," The Econometrics Journal, 2018, 21 (2), 114-135.

Morten, Melanie and Jaqueline Oliveira, "The Effects of Roads on Trade and Migration: Evidence from a Planned Capital City," NBER Working Paper, 2016, 22158.

Moukassa, A, D NSSOSSO, and G Mavah, "Occupation de l'espace forestier par les communautés villageoises et semi-nomades dans les UFA Kabo, Pokola, Toukoulaka et Loundoungou (Nord Congo)," WCS, MEFE, PROGEPP, 2005.

Nebel, Gustav, Lincoln Quevedo, Jette Bredahl Jacobsen, and Finn Helles, "Development and economic significance of forest certification: the case of FSC in Bolivia," Forest Policy and Economics, 2005, 7 (2), 175-186.

Newton, Peter, Daniel C. Miller, Mugabi Augustine Ateenyi Byenkya, and Arun Agrawal, "Who are forest-dependent people? A taxonomy to aid livelihood and land use decision-making in forested regions," Land Use Policy, 2016, 57, 388 - 395. 
Olivero, Jesús, John E. Fa, Miguel A. Farfán, Jerome Lewis, Barry Hewlett, Thomas Breuer, Giuseppe M. Carpaneto, María Fernández, Francesco Germi, Shiho Hattori, Josephine Head, Mitsuo Ichikawa, Koichi Kitanaishi, Jessica Knights, Naoki Matsuura, Andrea Migliano, Barbara Nese, Andrew Noss, Dieudonné Ongbwa Ekoumou, Pascale Paulin, Raimundo Real, Mike Riddell, Edward G. J. Stevenson, Mikako Toda, J. Mario Vargas, Hirokazu Yasuoka, and Robert Nasi, "Distribution and Numbers of Pygmies in Central African Forests," PLOS ONE, 01 2016, 11 (1), 1-16.

Quintana-Murci, Lluis, Hélène Quach, Christine Harmant, Francesca Luca, Blandine Massonnet, Etienne Patin, Lucas Sica, Patrick Mouguiama-Daouda, David Comas, and Shay Tzur, "Maternal traces of deep common ancestry and asymmetric gene flow between Pygmy hunter-gatherers and Bantu-speaking farmers," Proceedings of the National Academy of Sciences, 2008, 105 (5), 1596-1601.

Remis, Melissa J and Carolyn A Jost Robinson, "Examining short-term nutritional status among BaAka foragers in transitional economies," American Journal of Physical Anthropology, 2014, 154 (3), 365-375.

Riddell, Michael, "Assessing the Impacts of Conservation and Commercial Forestry on Livelihoods in Northern Republic of Congo," 09 2013, 11, 199-217.

- and Henri Obongo, "Hunting and rural livelihoods in northern Republic of Congo: local outcomes of integrated conservation and development," Technical Report, Oxford University Centre for the Environment February 2011.

Robinson, Carolyn A Jost and Melissa J Remis, "BaAka women's health and subsistence practices in transitional conservation economies: Variation with age, household size, and food security," American Journal of Human Biology, 2016, 28 (4), 453-460.

Roodman, David, James G. MacKinnon, Morten Orregard Nielsen, and Matthew D. Webb, "Fast and Wild: Bootstrap Inference in Stata Using boottest," Working Papers 1406, Queen's University, Department of Economics June 2018.

Wahlén, Catherine Benson, "Opportunities for making the invisible visible: Towards an improved understanding of the economic contributions of NTFPs," Forest Policy and Economics, 2017, 84, 11 - 19. Forest, Food, and Livelihoods.

Webb, Matthew D., "Reworking Wild Bootstrap Based Inference for Clustered Errors," Queen's Economics Department Working Paper 1315, Kingston, Ont. 2013.

Wilkie, David, Ellen Shaw, Fiona Rotberg, Gilda Morelli, and Philippe Auzel, "Roads, development, and conservation in the Congo Basin," Conservation Biology, 2000, 14 (6), 1614-1622. 
Table 1: Summary Statistics

\begin{tabular}{lccccc}
\hline \hline & mean & sd & $\min$ & $\max$ & $\mathrm{N}$ \\
\hline Households & & & & & \\
\hline No Starch Yesterday & 0.142 & 0.350 & 0 & 1 & 197 \\
No Starch Day Before Yesterday & 0.152 & 0.360 & 0 & 1 & 197 \\
No Starch Last Two Days & 0.076 & 0.266 & 0 & 1 & 197 \\
No Protein Yesterday & 0.330 & 0.471 & 0 & 1 & 197 \\
No Protein Day Before Yesterday & 0.259 & 0.439 & 0 & 1 & 197 \\
No Protein Last Two Days & 0.137 & 0.345 & 0 & 1 & 197 \\
Certified Village & 0.619 & 0.487 & 0 & 1 & 197 \\
Bantu * Certified & 0.264 & 0.442 & 0 & 1 & 197 \\
Bantu & 0.442 & 0.498 & 0 & 1 & 197 \\
Female & 0.137 & 0.345 & 0 & 1 & 197 \\
Value of Material Assets, Log (FCFA) & 11.338 & 1.022 & 7.199 & 14.986 & 189 \\
\hline Individuals & & & & & \\
\hline Sick last two weeks & 0.771 & 0.420 & 0 & 1 & 896 \\
Certified Village & 0.610 & 0.488 & 0 & 1 & 896 \\
Bantu * Certified & 0.246 & 0.431 & 0 & 1 & 896 \\
Bantu & 0.415 & 0.493 & 0 & 1 & 896 \\
Female & 0.502 & 0.500 & 0 & 1 & 896 \\
Age in years & 22.664 & 21.378 & 0 & 90 & 896 \\
\hline \hline
\end{tabular}

Notes: The number of observations differs for value of material assets because eight households did not finish the survey; the inventory of household assets was near the end of the survey questions. 
Table 2: Balance Tests

\begin{tabular}{lccc}
\hline & Certified & Uncertified & P-value \\
\hline BaAka (Indigenous) & 0.574 & 0.533 & 0.582 \\
Fisher & 0.795 & 0.787 & 0.889 \\
Planted field & 0.868 & 0.841 & 0.616 \\
Educated & 0.767 & 0.743 & 0.716 \\
Can read & 0.174 & 0.100 & 0.143 \\
Residents in household & 3.992 & 3.920 & 0.805 \\
Men in Household & 1.098 & 1.160 & 0.535 \\
Children in Household & 2.164 & 2.213 & 0.830 \\
Visitors in household & 0.0246 & 0.0933 & 0.313 \\
Female-headed household & 0.0902 & 0.213 & 0.0251 \\
\hline
\end{tabular}

Notes: The table presents results from t-tests where the unit of observation is the household head or household. The first and second column report averages for households in Certified and Uncertified villages. The third column reports the p-value from a two-tailed test where the sample sizes are unequal. 
Table 3: Differences in Food Consumption

\begin{tabular}{|c|c|c|c|}
\hline & Yesterday & Two Days Ago & Last Two Days \\
\hline \multicolumn{4}{|c|}{ Panel A: No Farmed Starch Consumption } \\
\hline \multirow[t]{3}{*}{ Certified Village } & $0.145^{+}$ & $0.297^{* *}$ & $0.126^{* *}$ \\
\hline & $(0.08)$ & $(0.06)$ & $(0.04)$ \\
\hline & {$[0.099]$} & {$[0.001]$} & {$[0.008]$} \\
\hline \multirow[t]{3}{*}{ Bantu \& Certified } & $-0.143^{*}$ & $-0.325^{* *}$ & $-0.149^{*}$ \\
\hline & $(0.06)$ & $(0.08)$ & $(0.05)$ \\
\hline & {$[0.035]$} & {$[0.003]$} & {$[0.024]$} \\
\hline Observations & 197 & 197 & 197 \\
\hline$R^{2}$ & 0.118 & 0.210 & 0.078 \\
\hline \multicolumn{4}{|c|}{ Panel B: No Protein Consumption } \\
\hline \multirow[t]{3}{*}{ Certified Village } & $0.324^{* *}$ & $0.189^{*}$ & $0.154^{* *}$ \\
\hline & $(0.10)$ & $(0.08)$ & $(0.04)$ \\
\hline & {$[0.010]$} & {$[0.039]$} & {$[0.004]$} \\
\hline \multirow[t]{3}{*}{ Bantu \& Certified } & -0.206 & 0.093 & -0.069 \\
\hline & $(0.12)$ & $(0.11)$ & $(0.07)$ \\
\hline & {$[0.130]$} & {$[0.407]$} & {$[0.343]$} \\
\hline Observations & 197 & 197 & 197 \\
\hline$R^{2}$ & 0.104 & 0.085 & 0.093 \\
\hline
\end{tabular}

Notes: The table presents results from six separate regressions where an observation is a household. The outcome variable for Panel A is a dummy variable equal to one if the household failed to report eating starch the previous day (column 1), the day before (column 2), or anytime over the last two days (column 3). The outcome variable for the bottom panel is a dummy equal to one if the household failed to report eating protein over the same horizons. The omitted category is BaAka, the indigenous group. All regressions include a dummy for Bantu, female, and a constant. Coefficients are followed by standard errors clustered by village, in parentheses. P-values from hypothesis testing based on subcluster wild bootstrapping using boottest (Roodman et al. 2018) are reported in brackets. 
Table 4: Differences in Reported Illness

\begin{tabular}{|c|c|c|c|c|}
\hline & All & Older Adults & Middle Aged & Children \\
\hline \multicolumn{5}{|c|}{ Panel A: All individuals } \\
\hline \multirow{3}{*}{ Certified Village } & $0.108^{* *}$ & $0.194^{+}$ & $0.071^{+}$ & 0.090 \\
\hline & $(0.02)$ & $(0.10)$ & $(0.03)$ & $(0.06)$ \\
\hline & {$[0.001]$} & {$[0.077]$} & {$[0.054]$} & {$[0.182]$} \\
\hline \multirow{3}{*}{ Bantu \& Certified } & $-0.165^{* *}$ & $-0.292^{*}$ & -0.108 & -0.129 \\
\hline & $(0.03)$ & $(0.09)$ & $(0.08)$ & $(0.09)$ \\
\hline & {$[0.001]$} & {$[0.015]$} & {$[0.204]$} & {$[0.187]$} \\
\hline \multirow{2}{*}{$\begin{array}{l}\text { Observations } \\
R^{2}\end{array}$} & 896 & 155 & 337 & 404 \\
\hline & 0.034 & 0.095 & 0.013 & 0.059 \\
\hline \multicolumn{5}{|c|}{ Panel B: Women and Girls } \\
\hline \multirow[t]{3}{*}{ Certified Village } & $0.117^{* *}$ & $0.387^{*}$ & 0.102 & -0.007 \\
\hline & $(0.03)$ & $(0.13)$ & $(0.06)$ & $(0.14)$ \\
\hline & {$[0.008]$} & {$[0.019]$} & {$[0.142]$} & {$[0.962]$} \\
\hline \multirow[t]{3}{*}{ Bantu \& Certified } & $-0.195^{*}$ & $-0.418^{*}$ & -0.125 & -0.113 \\
\hline & $(0.07)$ & $(0.13)$ & $(0.11)$ & $(0.14)$ \\
\hline & {$[0.024]$} & {$[0.012]$} & {$[0.300]$} & {$[0.455]$} \\
\hline \multirow{2}{*}{$\begin{array}{l}\text { Observations } \\
R^{2}\end{array}$} & 450 & 85 & 170 & 195 \\
\hline & 0.050 & 0.279 & 0.012 & 0.102 \\
\hline \multicolumn{5}{|c|}{ Panel C: Men and Boys } \\
\hline \multirow[t]{3}{*}{ Certified Village } & $0.102^{*}$ & -0.037 & 0.036 & $0.166^{*}$ \\
\hline & $(0.04)$ & $(0.10)$ & $(0.04)$ & $(0.05)$ \\
\hline & {$[0.027]$} & {$[0.735]$} & {$[0.443]$} & [0.014] \\
\hline \multirow[t]{3}{*}{ Bantu \& Certified } & $-0.136^{+}$ & -0.151 & -0.087 & -0.104 \\
\hline & $(0.07)$ & $(0.14)$ & $(0.07)$ & $(0.13)$ \\
\hline & {$[0.078]$} & {$[0.303]$} & {$[0.238]$} & {$[0.458]$} \\
\hline \multirow{2}{*}{$\begin{array}{l}\text { Observations } \\
R^{2}\end{array}$} & 446 & 70 & 167 & 209 \\
\hline & 0.022 & 0.060 & 0.019 & 0.049 \\
\hline
\end{tabular}

Notes: The table presents results from nine separate regressions where an observation is an individual.

The outcome variable for all regressions is a dummy variable equal to one if the individual reported being sick within the previous two weeks. The first column includes all individuals; column 2 restricts to people 45 years or older; column 3 includes people between 10 and 45 years old; and column 4 includes people 10 and under. Panel A includes all individuals, Panel B restricts the sample to women and girls, and Panel $\mathrm{C}$ restricts the sample to men and boys. The omitted category is BaAka, the indigenous group. All regressions include a dummy for Bantu, female, linear and quadratic age terms, and a constant. Coefficients are followed by standard errors clustered by village, in parentheses. P-values from hypothesis testing based on subcluster wild bootstrapping using boottest (Roodman et al. 2018) are reported in brackets. 
Table 5: Differences in Asset Value Quantiles

\begin{tabular}{|c|c|c|c|c|}
\hline & OLS & p15 & p50 & p85 \\
\hline \multicolumn{5}{|c|}{ Panel A: BaAka Households } \\
\hline Certified Village & $\begin{array}{l}-0.102 \\
(0.128)\end{array}$ & $\begin{array}{l}-0.342^{*} \\
(0.160)\end{array}$ & $\begin{array}{c}-0.0888 \\
(0.115)\end{array}$ & $\begin{array}{l}0.0699 \\
(0.223)\end{array}$ \\
\hline Female & $\begin{array}{l}-0.498^{*} \\
(0.213)\end{array}$ & $\begin{array}{l}-0.376 \\
(0.260)\end{array}$ & $\begin{array}{c}-0.465^{* *} \\
(0.163)\end{array}$ & $\begin{array}{l}-0.578^{*} \\
(0.255)\end{array}$ \\
\hline Constant & $\begin{array}{l}10.78^{* *} \\
(0.109)\end{array}$ & $\begin{array}{l}10.42^{* *} \\
(0.111)\end{array}$ & $\begin{array}{c}10.83^{* *} \\
(0.0807)\end{array}$ & $\begin{array}{l}11.13^{* *} \\
(0.196)\end{array}$ \\
\hline $\begin{array}{l}\text { Observations } \\
R^{2}\end{array}$ & $\begin{array}{c}102 \\
0.053\end{array}$ & 102 & 102 & 102 \\
\hline \multicolumn{5}{|c|}{ Panel B: Bantu Households } \\
\hline Certified Village & $\begin{array}{l}-0.179 \\
(0.184)\end{array}$ & $\begin{array}{l}-0.373 \\
(0.315)\end{array}$ & $\begin{array}{l}-0.107 \\
(0.159)\end{array}$ & $\begin{array}{r}-0.0553 \\
(0.236)\end{array}$ \\
\hline Female & $\begin{array}{l}-0.175 \\
(0.223)\end{array}$ & $\begin{array}{c}-0.932^{+} \\
(0.507)\end{array}$ & $\begin{array}{c}0.125 \\
(0.327)\end{array}$ & $\begin{array}{l}0.0955 \\
(0.345)\end{array}$ \\
\hline Constant & $\begin{array}{l}12.27^{* *} \\
(0.154)\end{array}$ & $\begin{array}{l}11.87^{* *} \\
(0.166)\end{array}$ & $\begin{array}{l}12.25^{* *} \\
(0.140)\end{array}$ & $\begin{array}{l}12.82^{\text {** }} \\
(0.212)\end{array}$ \\
\hline $\begin{array}{l}\text { Observations } \\
R^{2}\end{array}$ & $\begin{array}{c}87 \\
0.016\end{array}$ & 87 & 87 & 87 \\
\hline
\end{tabular}

Notes: The table presents results from eight separate regressions where an observation is a household.

The outcome variable for all regressions is the natural log of household's asset value (in FCFA). The first column estimates the conditional expectation using OLS with clustered standard errors. Columns 2-4 use quantile regression to estimate the $15 \mathrm{th}, 50 \mathrm{th}$, and 75 th percentiles using bootstrapped standard errors. Panel A restrict the sample to BaAka households, Panel B restricts the sample to Bantu households. 


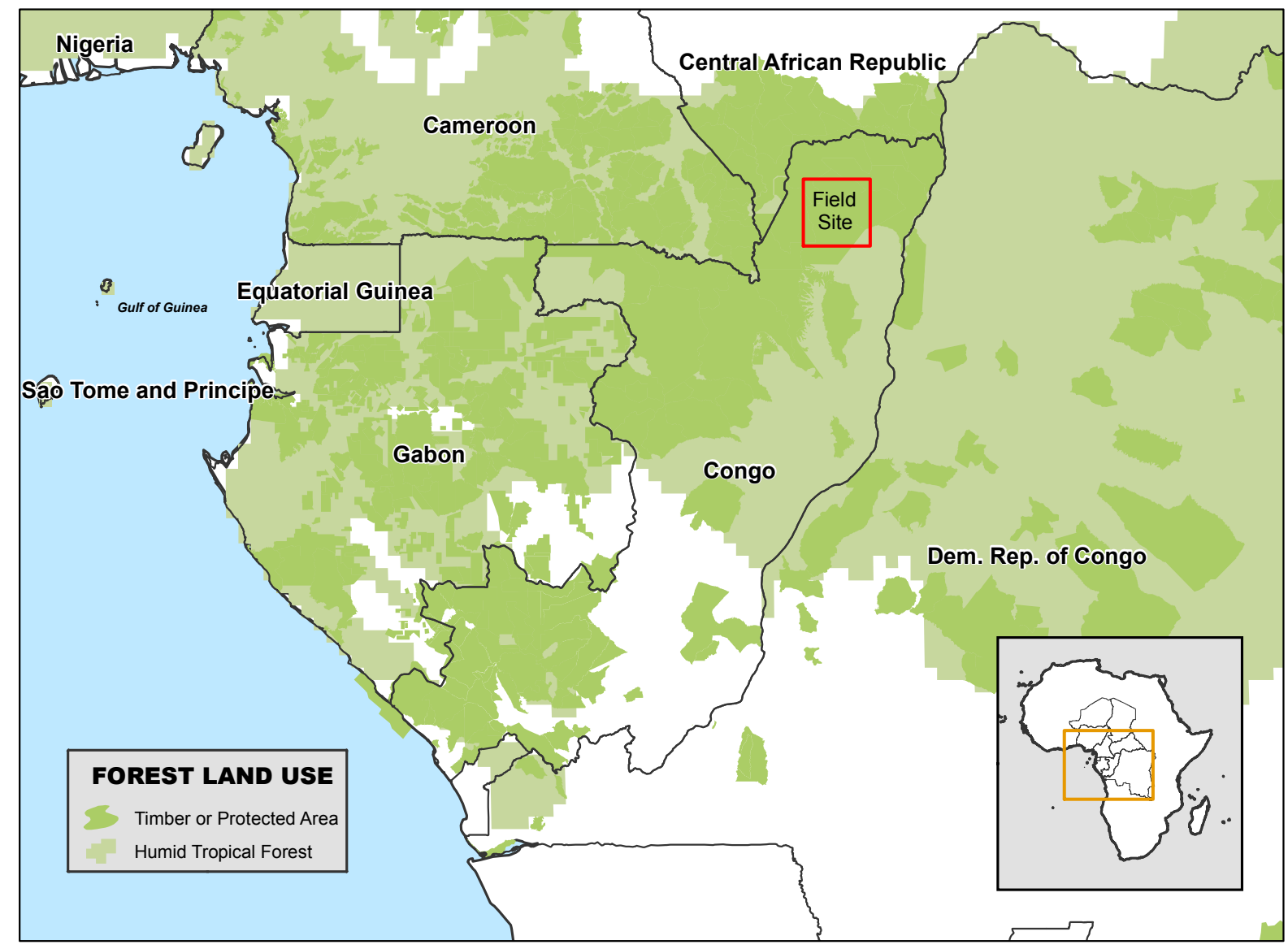

Figure I: Site within Congo Basin 


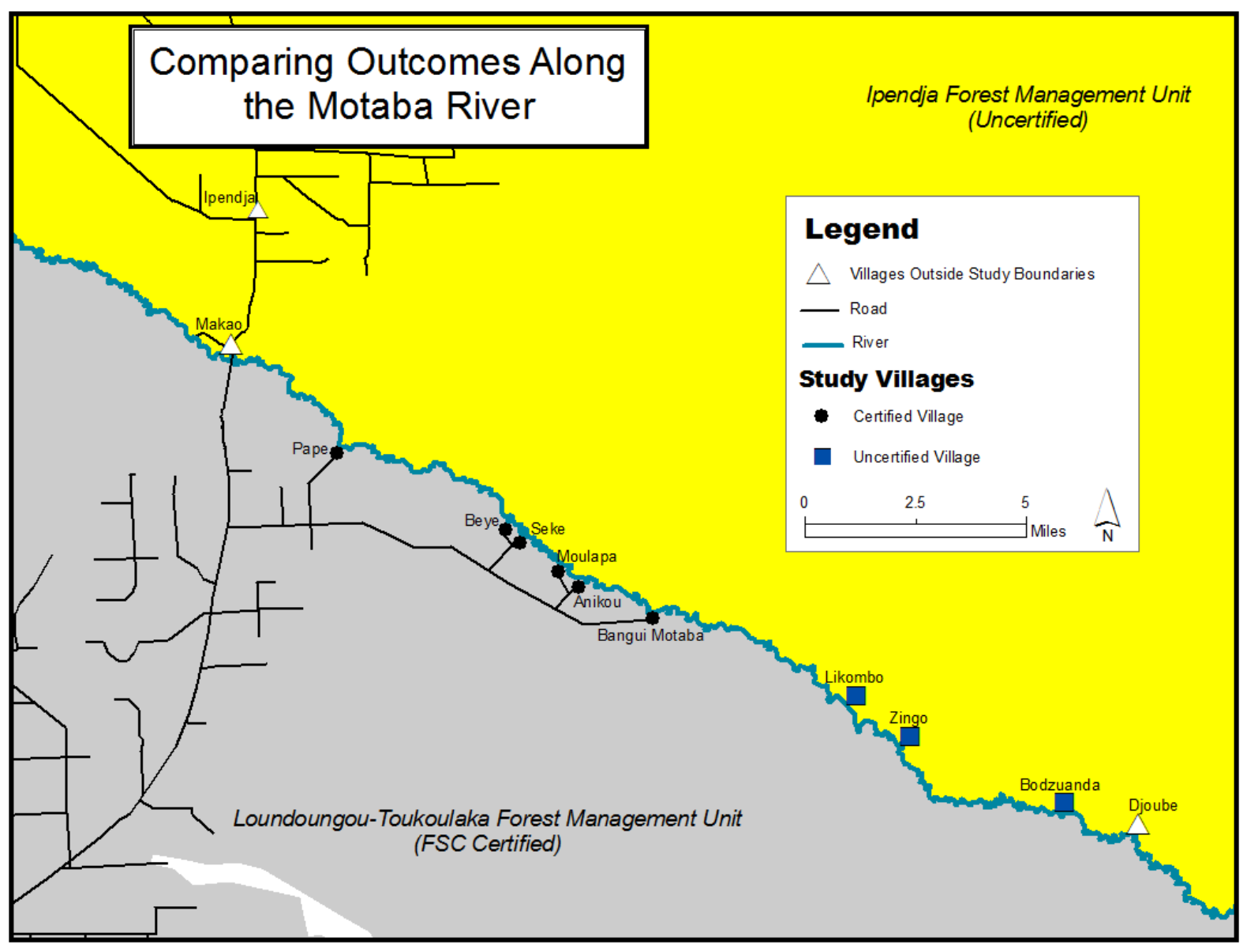

Figure II: Treatment Boundary 


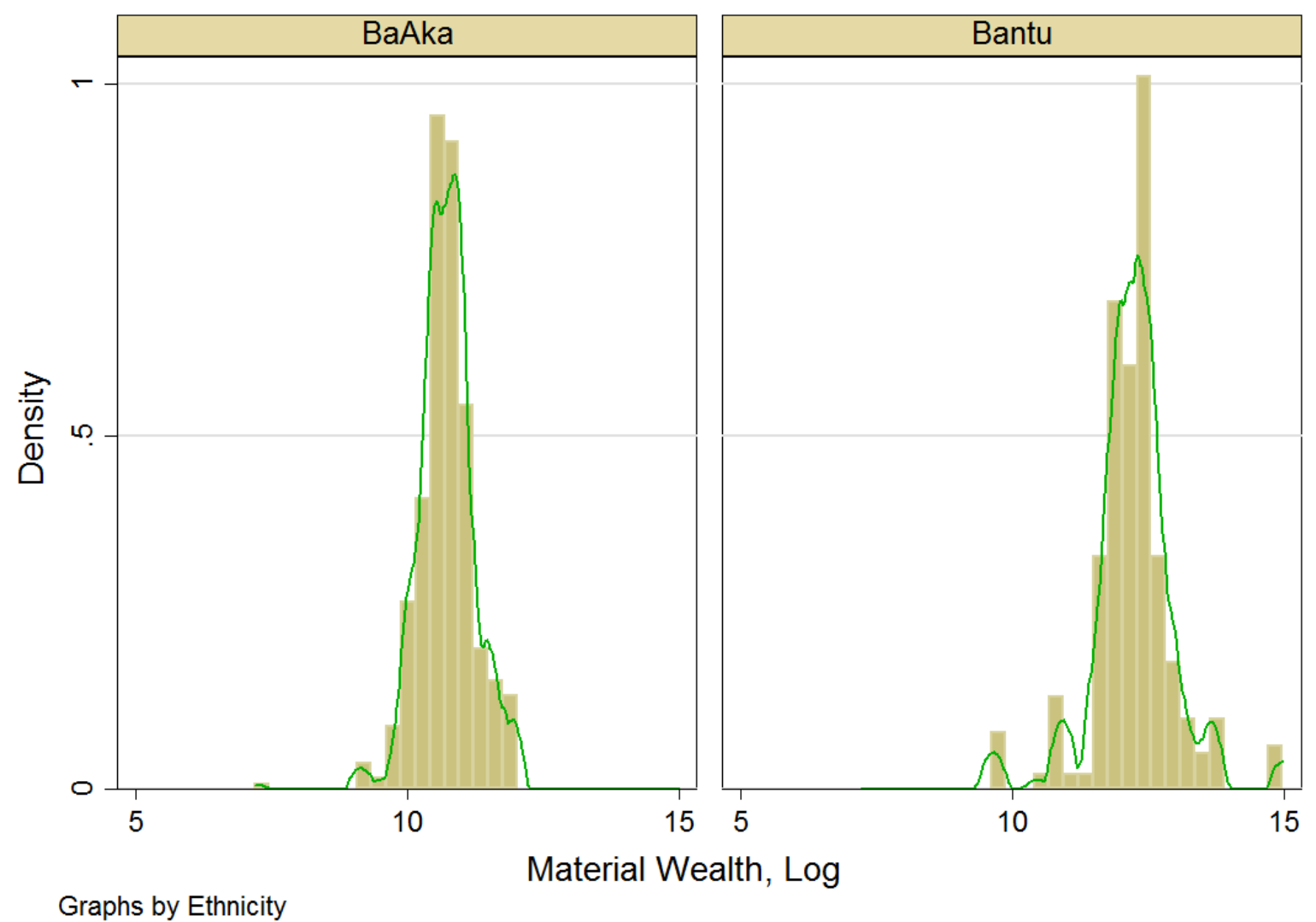

Figure III: Histogram of Material Wealth

Notes: The figure presents histograms and kernel density plots for the natural log of household material wealth, measured in FCFA, for BaAka (right) and Bantu (left) household. The bar areas are scaled such that their sum equals one. The kernel density uses the Epanechnikov kernel. 


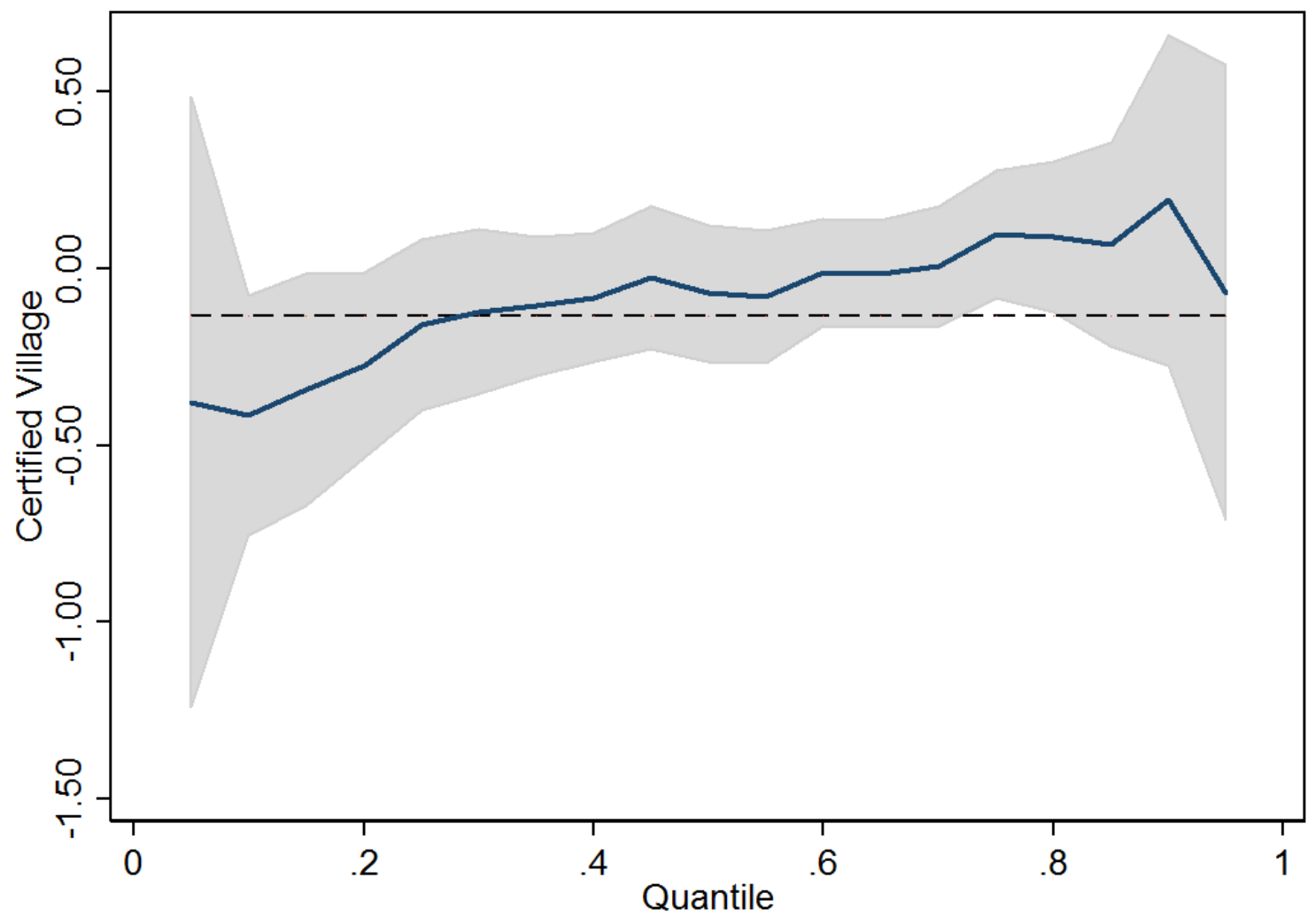

Figure IV: Quantile Regression Coefficients

Notes: The figure presents results from a quantile regression for the median including both BaAka and Bantu households using the grqreg command (Azevedo 2004). The outcome variable is the natural log of household's asset value in FCFA. The regression includes a dummy variable for female-headed households and Bantu ethnicity. The dashed line is the OLS coefficient for the Certified Village dummy variable. The blue line connects the quantile regression coefficient estimates for Certified Village for each decile and the shaded area is the $95 \%$ confidence interval. 


\section{Supplemental Appendix: For Online Publication, Only}

Table A1: Documenting Village Visitation

\begin{tabular}{lcrrrr}
\hline village & FSC & Latitude & Longitude & $\begin{array}{r}\text { Survey } \\
\text { Start Day }\end{array}$ & $\begin{array}{r}\text { Survey End } \\
\text { Day }\end{array}$ \\
\hline Anikou & 1 & 2.51938 & 17.28497 & 76 & 79 \\
Bangui Motaba & 1 & 2.50582 & 17.31132 & 5 & 36 \\
Beye & 1 & 2.52981 & 17.27217 & 58 & 63 \\
Bodzuanda & 0 & 2.44231 & 17.44804 & 64 & 69 \\
Likombo & 0 & 2.47728 & 17.37473 & 45 & 57 \\
Moulapa & 1 & 2.52244 & 17.28228 & 70 & 79 \\
Pape & 1 & 2.56042 & 17.21312 & 1 & 3 \\
Seke & 1 & 2.53211 & 17.26872 & 59 & 63 \\
Zingo & 0 & 2.46708 & 17.38973 & 38 & 44 \\
Total & 0 & 2.49745 & 17.33168 & 1 & 79 \\
\hline
\end{tabular}




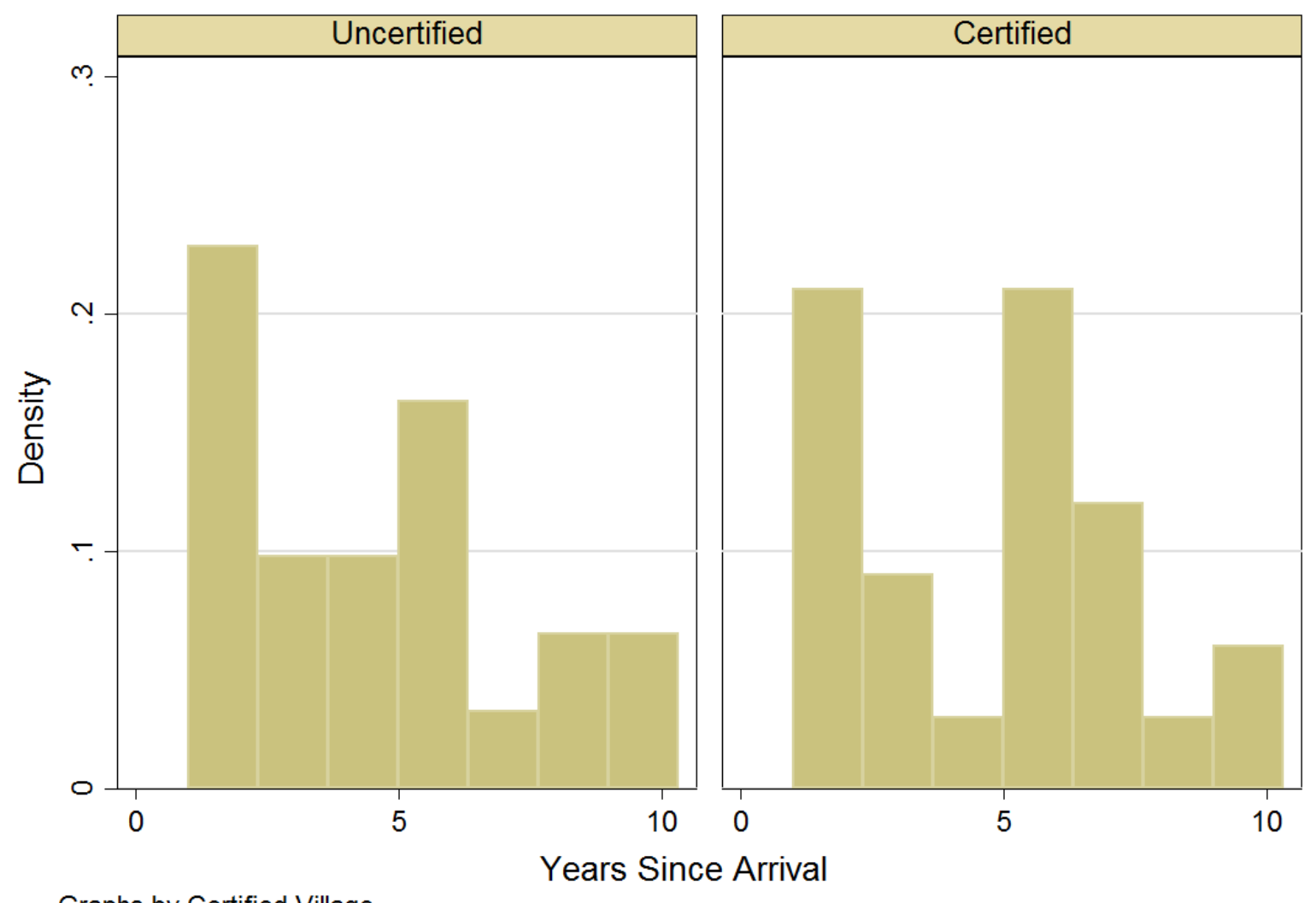

Figure AI: Histogram of Recent Arrivals

Notes: The figure compares the frequency of recent arrivals by exposure to certification. The population is restricted to the 48 households that arrived less than ten years before. The $\mathrm{x}$-axis is the years since the household arrived in the village. 